further power stations at Chooz and Cattenoom, close to the Luxembourg and Belgian borders.

The previous day, environmental groups from Luxembourg, France and Belgium had called a press conference in Luxembourg and denounced the French government's total disregard for the principles and rules of international law. The French, however, are not the only culprits. Of the 120 or so nuclear power stations at present in operation, under construction or planned in the European Community, 33 are less than 25 miles from national borders and another 15 are less than 6 miles from borders.

Von Alemann's report urges the introduction of Community safety norms and the implementation of a Community consultation procedure, bolstered by an EEC regulation. During the debate many speakers called for a broader interpretation of Articles 37 and 41 of the Euratom Treaty. These relate to the obligation of member states to supply the European

\section{French take Manhattan}

A French firm has stormed the US optical communications market - and installed a $6.5-\mathrm{km}$ optical fibre system in Manhattan. CIT-Alcatel, the leading French telecommunications company, announced last week that it had beaten off competition - including the giant ITT - to supply the link to Western Union cable and telegraph company. They system will be the first fully operational optical fibre link in the United States CIT officials believe.

CIT will also supply the second such link, an experimental one which the company sold to Western Union a year ago. When the new link, which uses light emitting diodes to convert electrical signals into light, goes into operation in January, the experimental link (which uses laser diodes) will also be put into regular use. CIT will thus gain operating experience with the two principal competing technologies for optical fibre input.

The great advantage of optical fibre systems for Manhattan is that available cable ducts under the city are physically crammed to capacity, and it is now almost impossible to feed through standard electrical links. Optical fibre links, however, can be made on cables 10 times smaller in outer diameter - allowing a hundredfold increase in channel capacity for the same duct cross-section.

The CIT system uses cables, supplied by another company, of $1 \mathrm{~cm}$ outer diameter to carry 44 megabits per second (672 telex channels). CIT supplied the input-output devices and the data management systems for the link. CIT considers that this first step in the US market is "fundamental" and that the potential scale of the market is "huge".

Robert Walgate
Commission with all data on radioactive effluent capable of causing pollution and details of all future plans for nuclear power stations.

French parliamentarians of all political hues united against the attack, claiming that it compromised national sovereignty. Pierre Calvez (French, Liberal) said he was opposed to any Community decision which transcended national policy. He added that all new power stations were subject to bilateral agreements and international regulations.

Speaking on behalf of the European Commission, acting Energy Commissioner Etienne Davignon declared that France had not infringed the Euratom Treaty and that the treaty could not be interpreted in such a light as to give the Commission the right to interfere.

Stanley Johnson (UK, Conservative) reminded the parliament of the fate of the so-called Séveso Directive at the last meeting of the Environment Council in June. The draft directive on the prevention of major accidents was not adopted because the French objected to the provisions for transboundary notification procedures. A compromise formula over this problem is now being thrashed out and it is hoped that the next council meeting on 12 December will adopt the text.

The EEC's energy ministers, when they met in Brussels on 27 November, briefly discussed the problems associated with the siting of nuclear power stations near boundaries. The draft regulation on the Community consultation procedure for electricity power stations that affect the territory of another member state has been held up in the council for several years. It now seems likely that this regulation will be looked at more seriously and its progress accelerated.

Jasper Becker

\section{Soviet health}

\section{More research}

A high-level cooperation programme between Soviet scientists and doctors will be an important feature of the next Five Year Plan for public health. This was decided by a joint session of the Academy of Sciences and the Academy of Medical Sciences last month. An interdepartmental scientific council is to be established, and a joint research programme is being drawn up. This says Academician Anatolii Aleksandrov, president and chairman of the new council of the Academy of Sciences, will reflect the main problems in public health and take into account the potential of the country's scientific institutes.

Aleksandrov reported that cooperation between scientists and medical teams has already led to some major advances, including medical applications of ultrasonics, cryogenics and laser technology. The Minister of Public Health, Boris Petrovskii, spoke warmly of the raised standards of diagnosis and treatment made possible by the introduction of new techniques in cardiology, oncology, surgery, paediatrics and pharmacology.

Molecular biology, which until the mid-1970s was neglected in the Soviet Union, received a glowing tribute from $\mathrm{Dr}$. Nikolai Blokhin, President of the Academy of Medical Sciences. Recent results, he said, opened up prospects for the establishment of new ideas about the nature of viruses, malignant changes in cells, human heredity and the development of genetic engineering techniques. Other innovations are less welcome. The MarxistLeninist world outlook, said Blokhin, protected Soviet medicine from mysticism, parapsychology, the psychosomatic theories of Freud, various types of neoFreudianism and other "views that could lead medicine astray". He called therefore for greater cooperation between medical workers and representatives of the philosophical institutes of the Academy of Sciences.

Vera Rich

Polish science

\section{Advice not taken}

The Gierek regime consistently "torpedoed or disavowed" constructive criticisms from its nine-person team of scientific advisers. So claims Professor Alojzy Melich, a member of the team since its inauguration in 1977, in an interview in Trybuna Robotnicza, the daily paper of Katowice (Mr Gierek's home power-base).

Professor Melich said that during the past three years, the team had prepared about a dozen comprehensive surveys on the main problems facing the country, as well as numerous smaller papers and analysis. These, however, were rejected by the government and the planning commission, simply because they attacked current policies. In the end, Professor Melich said, the government simply stopped providing its scientific advisers with any information at all.

This is not the first such accusation to be levelled in recent months. In August, an ad hoc farmers' committee which has since become the nucleus of the farmers' campaign for trade union representation, accused the authorities of suppressing expert reports on the deterioration of Polish agriculture. Unlike most critics, however, Professor Melich did not condemn Mr Gierek's policy of obtaining massive foreign loans to back his investment projects; these, said Melich, had provided an important stimulus for the economy.

The current economic crisis, however, has meant that the future of many major investment projects has become doubtful. Even the much hailed Programme-Wisla is liable to suffer some cutbacks at least for the present. This scheme, which was envisaged as a major contribution to Poland's economy in the twenty-first century, consists of a broad range of water- 


\section{Cable of protest}

One hundred and six Fellows of the Royal Society, including four Nobel Prize Winners, (Sir Nevill Mott, Sir Max Perutz, Sir George Porter, and Dr Fred Sanger) have sent the following telegram to the Soviet Delegation to the Madrid Review Conference.

"The arrest of Dr Brailovskii is a cause of great concern which can only harm further scientific exchange between our countries."

Viktor Brailovskii, arrested on 13 November, the day after the opening of the Madrid Conference, is thought to be facing charges under Article 191/1 of the Soviet Penal Code: Disseminating information known to be false and detrimental to the Soviet Union and socialist system. His detention, however, seems to be linked with his activity as host to the Sunday seminars for Jewish refusnik scientists in Moscow. Last week, his wife was warned by the security authorities not to try to go ahead with the seminar. When, on Sunday, she attempted to hold the seminar, intending participants were prevented by the police from entering the apartment.

In Washington last Sunday, the Committee of Concerned Scientists organized a seminar on the style of the Moscow seminar. A paper was read by $\mathrm{Dr}$ Maxine Singer who earlier this year was refused a visa to visit Moscow, where she had intended to visit the Brailovskii seminar. Several of the participants had read papers at the Brailovskii seminar during professional visits to Moscow. It is hoped to hold such seminars every Sunday in various US academic centres.

An international delegation of scientists, led by the French Nobel Laureate Andre Lwoff, who is a corresponding member of the Soviet Academy of Medical Sciences, is seeking a meeting with Ilichev, head of the Soviet delegation in Madrid, to discuss the Brailovskii case.

Vera Rich

managed developments, ranging. from recreation to heavy transport, with canal links through the Soviet Union and East Germany. Such a major project cannot, of course, be simply abandoned, but as the press spokesman for the programme recently pointed out, it is a complex plan, the implementation of one part does not necessarily depend on that of another, and, in any case, the announced completion deadline of the year 2000 had rather "symbolic" significance. Nevertheless, he said, the country simply cannot afford not to implement some parts of the scheme as soon as possible - the anti-pollution and water-storage proposals which will be vital in the next few years if the country's agriculture and industry are to recover.

A similar stance was adopted recently in the Sejm (Parliament) by Deputy Zbigniew Kledecki. Speaking on the pollution of the
Krakow area by the Nowa Huta steel mills and the Skawina aluminium plant, he stated that the cost of installing modern, non-polluting equipment would be 120 million zloty ( $£ 2$ million) at Nowa Huta and 7,500 million zloty ( $£ 125$ million) at Skawina. Nevertheless, he said, in view of the grave pollution hazards and the "critical attitude of community scientists and journalists in Krakow", preparatory work on modernizing the plants would begin next year.

Important as such major investments still may be, the most immediate investment problem is that of agriculture. Recent pledges by the Minister of Agriculture, Leon Klonica, include an increase in the production of plant protection chemicals, and fertilizers, investments in land-improvement, development of an intermediate technology suitable for small farms, changes in the supply and pricing system to aid the private farmer, and a relaxation of central arbitrary planning in agriculture. These last points, which are a considerable reversal of recent policy, have been welcomed by the farmers with cautious approval.

Vera Rich

\section{Brazilian universities}

\section{No cash ahead}

\section{Sao Paulo, November}

Inflation and a lack of sympathy from the state government have forced the University of São Paulo (USP), Brazil's oldest university and one of its best, into a serious crisis. But the crisis is not confined to São Paulo. All government-supported universities face difficulties over dwindling budgets. Academics throughout Brazil have been protesting about the lack of resources by holding a series of one or twoday stoppages, the latest at the beginning of this month.

The academics' complaint is that the state and federal governments have made the universities take an unfair share of public expenditure cuts and have thus neglected the country's long-term future in the panic to service Brazil's massive foreign debt and oil import bill. This results in the universities having virtually no money for new building and very little for buying and maintaining equipment.

The most serious complaint, however, is the effect of inflation on academic salaries, which have recently been increasing at only about half the rate of inflation and which are corrected only once a year. (The academics are asking for termly readjustment.) The lack of money available for salaries has meant that some academics have to turn to part-time and piecework teaching. Many academics can get contracts for only 20 hours a week and have to eke out a living by other means. But even those with 40-hour contracts are finding it necessary to look for ways of topping up their incomes.

Salary problems seem to vary from one university to another and depend on how individual funds are administered. Some federal universities, called fundações, are allowed to keep their own trust funds which are being used to top up salaries, but others, the autarquias, are strictly limited to paying agreed government salaries only. For those in the humanities in the autarquias, the outlook is bleak, but for scientists there is a chance of extra support from the national research councils, which have recently started to top up researchers' salaries as well as making research grants. The budgets of the research councils have not, however, stretched to helping every scientist worthy of support.

The number of applications made to the main research council, the Conselho Nacional de Desenvolvimento Cientifico e Tecnologico (CNPq), for grants to supplement salaries increased dramatically in 1980. The CNPq estimates that it is now supplementing about 2,200 scientists' salaries and that its sister organizations may be supplementing as many as 3,000 . Most notable, says the $\mathrm{CNPq}$, is the large increase in applications from the University of São Paulo.

For federal universities, the $\mathrm{CNPq}$ is confident that the problem is only temporary and that the salaries problem will be alleviated by the beginning of the next academic year in March. The University of São Paulo, however, cannot necessarily expect such a reprieve. Its finances are controlled by the government of the state of Sao Paulo which allocates the budget annually - the most serious deterioration in the university's finances has occurred over the past few years, since a change in the state government.

If São Paulo has been hit more severely than most of the federal universities, it may be - according to one administrator - that the university had more to lose. But many academics and newspaper reports blame the crisis on the governor of Sao Paulo state, Paulo Maluf, who is keener on oil exploration projects than on the university.

The university's teachers' association says that its share of the state budget decreased from 3 per cent in 1975 to 1.89 per cent in 1980, and that the share taken by higher education generally decreased from 5.1 per cent to 3.3 per cent over the same period. The same figures put the average salary of a full-time professor at about 80,000 cruzeiros a month ( $£ 6,000$ a year), less than half of its maximum real value in the past decade. But budgets are not the only problem afflicting Brazilian universities. Their rapid expansion from 500,000 students in 1968 to 1.5 million now has led to unwieldy bureaucracies which changes of government have only aggravated. At São Paulo, the seat of university unrest in 1968, academics say that even relatively small items of expenditure have to be approved by the rector, who in turn has to argue for funds with the state government.

Judy Redfearn 